\title{
Enhancement of physicochemical characteristics of palm olein and winged bean (Psophocarpus tetragonolobus) seed oil blends ${ }^{\text {is }}$
}

\author{
Elina Hishamuddin ${ }^{1, *}$ (D) and Mei Huey Saw ${ }^{2}$ \\ ${ }^{1}$ Engineering and Processing Research Division, Malaysian Palm Oil Board (MPOB), 6 Persiaran Institusi, Bandar Baru Bangi, 43000 \\ Kajang, Selangor, Malaysia \\ 2 Product Development Research and Advisory Services Division, Malaysian Palm Oil Board (MPOB), 6 Persiaran Institusi, Bandar Baru \\ Bangi, 43000 Kajang, Selangor, Malaysia
}

Received 15 September 2021 - Accepted 1 December 2021

\begin{abstract}
Incorporation of oils from non-conventional sources into palm olein through the blending process generates a sustainable source of novel oleins with improved physicochemical and functional properties. The objective of this study was to evaluate the effects of blending winged bean (Psophocarpus tetragonolobus) seed oil (WBSO) and palm olein (POo) on the physicochemical properties of the blends. Blends of WBSO $(25,50$ and $75 \% \mathrm{w} / \mathrm{w})$ with POo were prepared and changes in fatty acid (FA) and triacylglycerol (TAG) compositions, iodine value (IV), cloud point and thermal behaviour were studied. Reductions in palmitic (C16:0) and oleic (C18:1) acids with concomitant increases in linoleic (C18:2) and behenic (C22:0) acids were observed as the amount of WBSO increased in the blends. Blending WBSO and POo at $75: 25$ increased the unsaturated FA content from $56 \%$ in palm olein to $64 \%$ in the blend, producing the highest IV of $70.5 \mathrm{~g} \mathrm{I}_{2} / 100 \mathrm{~g}$. At higher WBSO ratios, triunsaturated and diunsaturated TAG species within the blends increased while disaturated TAG species decreased. The lowest cloud point $\left(8.8^{\circ} \mathrm{C}\right)$ was obtained in the oil blend containing 50\% WBSO, while the cloud point further increased with increasing amount of WBSO in the blends. This was possibly attributed to increased trisaturated TAG with very longchained saturated FA (C20 to $\mathrm{C} 24)$ inherently present in WBSO within the blends. Thermal behaviour analysis by differential scanning calorimetry of the oil blends showed higher onset temperatures for crystallisation with increasing proportions of WBSO in POo, with melting thermograms correspondingly showing decreasing onset melting temperatures. These findings showed that blending WBSO with POo enhanced the physicochemical characteristics of the final oil blends, resulting in higher unsaturation levels and improved cloudiness resistance.
\end{abstract}

Keywords: winged bean (Psophocarpus tetragonolobus) seed oil / palm olein / blending / oil composition / physicochemical properties

Résumé - Amélioration des caractéristiques physicochimiques de mélanges d'oléine de palme et d'huile de graines de haricot ailé (Psophocarpus tetragonolobus). Le mélange d'oléine de palme et d'huiles de sources non conventionnelles représente une source durable de nouvelles oléines dotées de meilleures propriétés physicochimiques et fonctionnelles. L'objectif de cette étude était d'évaluer les effets du mélange d'huile de graines de haricot ailé (Psophocarpus tetragonolobus) (WBSO) et d'oléine de palme (POo) sur les propriétés physicochimiques des mélanges résultants. Des mélanges de WBSO (25, 50 et $75 \%$ $\mathrm{p} / \mathrm{p}$ ) et de POo ont été préparés et les changements de compositions en acides gras (FA) et triacylglycérols (TAG), d'indice d'iode (IV), de point de trouble et de comportement thermique ont été étudiés. La réduction des acides palmitique (C16:0) et oléique $(\mathrm{C} 18: 1)$ et l'augmentation concomitante des acides linoléique (C18:2) et béhénique (C22:0) ont été observées avec l'augmentation de la quantité de WBSO dans les mélanges. Le mélange de WBSO et de POo à 75:25 a fait passer la teneur en acides gras insaturés de 56\% dans l'oléine de palme à $64 \%$ dans le mélange, avec l'indice d'iode le plus élevée de $70,5 \mathrm{~g} \mathrm{I}_{2} / 100 \mathrm{~g}$. À des teneurs en WBSO plus élevées, les TAG tri-insaturés et di-insaturés dans les mélanges ont augmenté tandis

\footnotetext{
it Contribution to the Topical Issue "Minor oils from atypical plant sources / Huiles mineures de sources végétales atypiques".

*Correspondence: elina@mpob.gov.my
} 
que les TAG disaturés ont diminué. Le point de trouble le plus bas $\left(8,8^{\circ} \mathrm{C}\right)$ a été obtenu pour le mélange à $50 \%$ de WBSO, et il a augmenté encore avec la quantité de WBSO dans les mélanges. Cette observation est probablement liée à l'augmentation des TAG trisaturés par des AG saturés à très longue chaîne (C20 à C24) présents naturellement dans le WBSO. L'analyse du comportement thermique par calorimétrie à balayage différentiel des mélanges d'huiles a montré des températures de début de cristallisation plus élevées avec des proportions croissantes de WBSO dans POo, les thermogrammes de fusion montrant de manière correspondante des températures de début de fusion décroissantes. Ces résultats montrent que le mélange de la WBSO avec la POo améliore les caractéristiques physicochimiques des mélanges d'huiles finaux, ce qui se traduit par des niveaux d'insaturation plus élevés et une meilleure résistance au trouble.

Mots clés : huile de graines de haricot ailé (Psophocarpus tetragonolobus) / oléine de palme / mélange / composition de l'huile / propriétés physico-chimiques

\section{Introduction}

Palm olein (POo) is the liquid product from the fractionation of palm oil. In 2020, Malaysia produced more than 10.1 million tonnes of palm olein (MPOB, 2020). POo and its fractionated liquid products, namely super olein and top olein, find extensive applications in the production of cooking and salad oils (Parveez et al., 2020) and are often blended with other soft oils to produce oil blends with improved physical and chemical properties (Siddique et al., 2010). However, POo also exhibits cloudiness at low temperature that limits its usage in countries with cold climates (Siew and $\mathrm{Ng}, 1996$ ). Many studies in the past have reported on the advantages of blending POo with other soft oils such as soybean oil, sunflower oil and canola oil to improve its cold stability and clarity for use in temperate countries (NorAini et al., 1992, 1995; NorAini and Hanirah, 1996; Mamat et al., 2005), as well as for increasing oxidative stability and melting point depression (Siddique et al., 2010).

Winged bean, or scientifically known as Psophocarpus tetragonolobus is a tropical leguminous crop widely touted for its nutritive value as well as high protein and oil content (Ekpenyong and Borchers, 1980). It is mainly grown and cultivated in equatorial countries, i.e., Malaysia, Indonesia, Thailand, Bangladesh, India and West Africa, where the climate is relatively hot and humid. Many parts of the plant such as the pods, tuber, leaves and flowers are edible, either raw or cooked, and provide a rich source of energy, protein, vitamins and minerals for human and animals (Kadam et al., 1984). Previous literature reported that the mature seeds of winged bean yield protein and oil content between 29 to $38 \%$ and 12 to $18 \%$, respectively; with variations in the proximate values dependent upon the variety and oil extraction method employed (Černý et al., 1971; Garcia et al., 1979; Higuchi et al., 1982; Homma et al., 1983; Mohanty et al., 2014; Lepcha et al., 2017). Despite the potential of winged bean as a major multi-use food crop, it remains underutilized due to the reported presence of anti-nutrients such as parinaric acid, trypsin inhibitors, chymotrypsin inhibitors and hemagglutinins in the seeds (Černý et al., 1971; Mohanty et al., 2013), although several studies have shown the absence of parinaric acid in WBSO, thus rendering it safe for human consumption (Garcia et al., 1979; Higuchi et al., 1982; Mohanty et al., 2021). Cooking of winged bean seeds for several hours is generally required to destroy and eliminate trypsin inhibitors and hemagglutinins for improving digestibility (Kadam et al., 1984; Lepcha et al., 2017).
The oil of winged bean seed consists of 70 to $76 \%$ unsaturated fatty acids, and the fatty acid profile of winged bean seed oil has been reported to be similar to that of peanut oil (Garcia et al., 1979; Higuchi et al., 1982). Depending on the varieties and origins, the majority of fatty acids in winged bean seed oil (WBSO) comprises of a considerable amount of oleic and linoleic acids (58-74\%), followed by behenic acid (715\%) and palmitic acid (7-10\%) (Garcia et al., 1979; Higuchi et al., 1982; Mohanty et al., 2014; Makeri et al., 2016). The low amount of polyunsaturated fatty acids, especially linolenic $(<1 \%)$ and high proportion of saturated fatty acids in WBSO could potentially make it suitable for use in frying and in the formulation of zero-trans fat margarines and spreads due to its good oxidative stability property (Makeri et al., 2018).

Oils and fats derived from non-traditional sources provide a completely new avenue for research and development on their potential use and incorporation in food and non-food products. Blending is one of the cheapest and simplest methods for modifying oils and fats for creating new oil products with enhanced physical, chemical and nutritional properties (Hashempour-Baltork et al., 2016). Various studies have reported the advantages of improving physico-chemical characteristics and nutritional values of lipid-based foods using non-conventionally sourced oils. These include blends of pine nut oil/palm stearin for zero-trans margarine fat production (Adhikari et al., 2010), krabok (Irvingia Malayana) seed oil/coconut oil and mango seed fat/palm stearin for manufacturing cocoa butter replacers (Sonwai et al., 2015; Jahurul et al., 2014), blends of Moringa oleifera/palm olein and Moringa oleifera/palm stearin for formulating a highly stable frying oil and salad dressing as well as margarines and shortenings (Dollah et al., 2014) and blends of Opuntia ficusindica/Moringa oleifera for increasing oxidative stability (Salama et al., 2020), among others.

Recently, studies related to the physico-chemical properties of WBSO and its potential as raw material in the formulation of zero trans-fats margarines and spreads (Makeri et al., 2016, 2019) and frying fats (Makeri et al., 2018) have been reported. Due to its unsaturated nature, high oxidative stability and thermal stability, WBSO makes a suitable candidate for blending with POo to improve cloud point and resistance to crystallisation, in addition to potentially producing a good quality frying oil (Mohanty et al., 2021). However, to the best of the authors' knowledge, there have not been any studies examining how WBSO can potentially improve certain properties of POo, particularly in relation to increasing unsaturation levels and cloudiness resistance. 
Therefore, the aim of this study was to investigate the effect of blending different ratios of WBSO on the physicochemical and thermal properties of POo. By exploring new and nonconventional oils, this could possibly enhance the versatility of palm-based products, thereby ensuring continuous innovation in palm-based food development and sustainability in the oil palm industry.

\section{Materials and methods}

\subsection{Materials}

Refined, bleached and deodorised POo was purchased from MOI Foods Malaysia Sdn. Bhd. (Pulau Indah, Malaysia). Mature winged bean (Psophocarpus tetragonolobus) seeds were purchased from the Malaysian Agricultural Research and Development Institute (MARDI) (Klang, Malaysia).

\subsection{Reagents and standards}

Acetone, acetonitrile, $n$-hexane and methanol used in this study were of chromatographic grade and purchased from Merck (Darmstadt, Germany). Analytical grade petroleum ether $\left(60-80^{\circ} \mathrm{C}\right)$ was obtained from Fisher Chemicals (Loughborough, United Kingdom). Wijs solution and sodium were of analytical grade and purchased from Merck (Darmstadt, Germany). Fatty acid methyl esters (FAME) Mix RM-6, Grain FAME Mix and AOCS Low Erucic Rapeseed Oil were obtained from Sigma-Aldrich (St. Louis, MO, USA) while FAME Mix RM-5 was purchased from Supelco (Bellefonte, PA, USA).

\subsection{Oil extraction}

Mature winged bean seeds were ground using a laboratory blender (Waring Commercial, New Hartford, USA). Approximately $200 \mathrm{~g}$ of ground WBS was oven-dried for $4.5 \mathrm{~h}$ at $103{ }^{\circ} \mathrm{C}$ in open petri dishes to remove moisture until constant sample weight was achieved. Extraction of the oil from the ground WBS was carried out using petroleum ether in a $5 \mathrm{~L}$ Soxhlet extraction apparatus for $6 \mathrm{~h}$. The solvent was removed from the extract using a rotary evaporator under vacuum. The extracted oil was further dried at $103{ }^{\circ} \mathrm{C}$ for $1 \mathrm{~h}$ before left to cool. Oil samples were stored in amber glass bottles and refrigerated at $4{ }^{\circ} \mathrm{C}$ prior to blending, physicochemical properties and thermal behaviour analyses. The extracted WBSO used in this study was not further refined, therefore it still contained small amounts of free fatty acids, partial glycerides, polar lipids and other unknown lipids (Homma et al., 1983).

\subsection{Blending}

Oil blends were prepared by blending WBSO with POo at different ratios (w/w) of 25,50 and $75 \%$. The resultant blends were homogenised thoroughly to ensure uniformity throughout and stored at $4{ }^{\circ} \mathrm{C}$ prior to analyses of selected physicochemical properties and thermal behaviour analyses.

\section{5 lodine value and cloud point analyses}

The oil blends were analysed for iodine value (IV) and cloud point following the procedure described in American Oil Chemists' Society (AOCS) (2013) Official Methods Cd 1d-92 and $\mathrm{Cc}$ 6-25, respectively. Each analysis was carried out in triplicates and the results were expressed as mean \pm standard deviation (SD).

\subsection{Fatty acid composition analysis}

The fatty acid composition of the oil blends were analysed according to AOCS Official Method Ce 1f-96. Methyl esters of fatty acids were analysed using an Agilent 6890 Series gas chromatography (GC) system (J \& W Scientific, Folsom, USA) equipped with a flame ionization detector (FID) (Agilent Technologies, Wilmington, USA) on a fused silica capillary column (BPX-70, $60 \mathrm{~m}$ length $\times 0.25 \mathrm{~mm}$ i.d. film thickness $0.25 \mu \mathrm{m}$, SGE Inc., Austin, TX). The column temperature was set at $192{ }^{\circ} \mathrm{C}$ while injector (with split ratio 100:1) and detector temperatures were both set at $250^{\circ} \mathrm{C}$. The flowrate of helium (purity $99.999 \%$ ) was set at $0.8 \mathrm{~mL} / \mathrm{min}$. FAME were identified based on the retention time of standards and comparisons with literature. Analyses were carried out in duplicates and reported as mean $\pm \mathrm{SD}$.

\subsection{Triacylglycerol composition analysis}

TAG analysis of the oil blends was performed by ultra-high performance liquid chromatography (U-HPLC) (ACQUITY UPLC H-Class System, Waters Corp., Milford, USA) according to AOCS Official Method Ce 5c-93 with minor modifications. Individual samples were solubilised in acetone to form a $5 \% \mathrm{w} / \mathrm{v}$ solution. About $1 \mu \mathrm{L}$ of the solution was injected into an ACQUITY UPLC ${ }^{\circledR}$ BEH C18 column (Waters Corp., Milford, USA) (Column specifications: particle size $1.7 \mu \mathrm{m}$, id. $2.1 \mathrm{~mm} \times 150 \mathrm{~mm}$ length) maintained at $30^{\circ} \mathrm{C}$. The eluent consisted of a mixture of acetone and acetonitrile in the ratio of $63.5: 36.5 \mathrm{v} / \mathrm{v}$ at a flowrate of $0.25 \mathrm{~mL} / \mathrm{min}$. TAG species were detected using a refractive index detector (Waters Corp., Milford, USA) at $35^{\circ} \mathrm{C}$. TAG peaks were identified by comparison with the retention times of TAG standards and literature. TAG concentrations were normalised based on the total TAG present in the sample. Analyses were carried out in duplicates and reported as mean $\pm \mathrm{SD}$.

\subsection{Thermal behaviour analysis}

Thermal properties of the oil blends were analysed using a differential scanning calorimeter (DSC), DSC-7 (Perkin Elmer, Norwalk, USA) following the method by Zaliha et al. (2004). Indium and $n$-decane standards were used for calibration at high and low temperature ranges, respectively. About 3-5 mg sample was weighed and hermetically sealed in an aluminium pan with an empty pan serving as reference. The samples were heated to $80^{\circ} \mathrm{C}$ for $10 \mathrm{~min}$ to destroy crystal memory, then cooled to $-40^{\circ} \mathrm{C}$ at $5^{\circ} \mathrm{C} / \mathrm{min}$ and held for $10 \mathrm{~min}$ before being heated to $80^{\circ} \mathrm{C}$ again at $5^{\circ} \mathrm{C} / \mathrm{min}$. The 
E. Hishamuddin and M.H. Saw: OCL 2022, 29, 2

Table 1. Fatty acid composition, iodine value and cloud point of palm olein and winged bean (Psophocarpus tetragonolobus) seed oil blends.

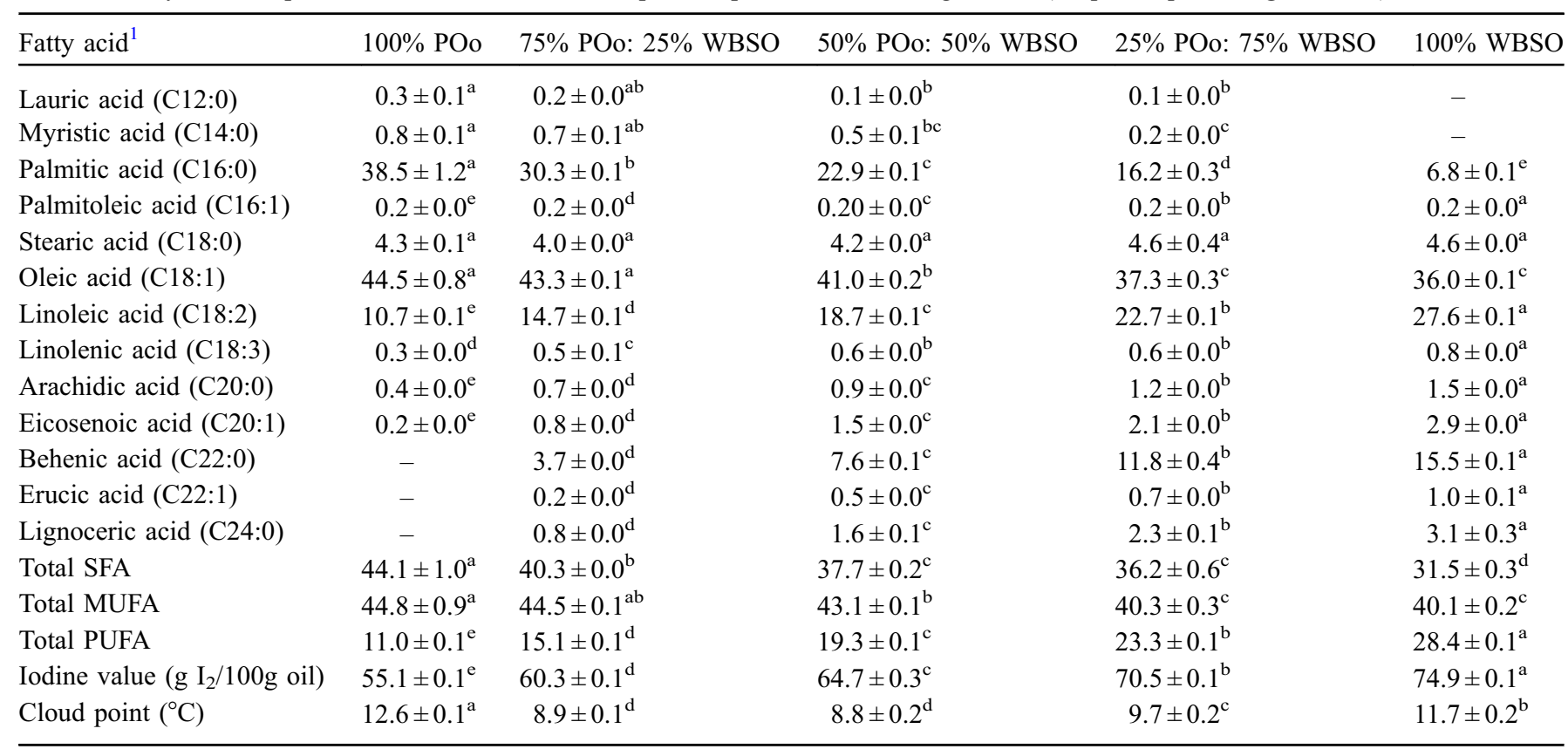

${ }^{1}$ SFA: saturated fatty acids; MUFA: mono-unsaturated fatty acids; PUFA: poly-unsaturated fatty acids.

Values with different letters across columns indicate significant differences at $p<0.05$.

WBSO: winged bean (Psophocarpus tetragonolobus) seed oil; POo: palm olein.

crystallisation and melting thermograms were recorded and the thermal properties, i.e., offset and onset temperatures, were determined for each sample.

\subsection{Statistical analysis}

One-way analysis of variance (ANOVA) was performed to evaluate significant differences between results using Tukey's test at $95 \%$ confidence level $(p<0.05)$. All statistical analyses were conducted using Minitab 16 software (Minitab Inc., State College, USA).

\section{Results and discussion}

\subsection{Fatty acid composition, iodine value and cloud point}

Table 1 tabulates the fatty acid composition, iodine value and cloud points of the pure oils and blends of POo and WBSO. The major saturated fatty acids present in POo are palmitic (38.5\%) and stearic (4.3\%) acids with lauric, myristic, palmitoleic, linolenic, arachidic and eicosenoic acids at concentrations below $1 \%$, respectively. In contrast, behenic $(15.5 \%)$, palmitic $(6.8 \%)$ and stearic $(4.6 \%)$ acids were the major saturated fatty acids in WBSO, followed by lignoceric and arachidic acids, in the order of decreasing concentrations. In both POo and WBSO, oleic (C18:1) and linoleic (C18:2) acids formed the main unsaturated fatty acids at $44.5 \%$ and $10.7 \%$, respectively in the former and $36.0 \%$ and $27.6 \%$, respectively in the latter. WBSO contains 3 very long chain fatty acids (C22-C24) which were not detected in POo, namely behenic, erucic and lignoceric acids while medium-chained lauric and myristic acids were not detected in WBSO but present in minute amounts in POo.

The differences in the fatty acid profile of the two oils significantly affected their degree of saturation whereby POo contains $44 \%$ saturated fatty acids (SFA) while WBSO contains about $31 \%$ SFA. Due to the considerably higher unsaturated fatty acids (USFA) content in WBSO which amount to slightly more than $68 \%$, WBSO possessed a significantly $(p<0.05)$ higher IV of $74.9 \mathrm{~g} \mathrm{I}_{2} / 100 \mathrm{~g}$ oil compared to POo with a lower IV of $55.1 \mathrm{~g} \mathrm{I}_{2} / 100 \mathrm{~g}$. This is consistent with the $70 \%$ USFA content in WBSO as reported by Makeri et al. (2016). The fatty acid composition of POo, presented in this study, is in agreement with that reported by Saw et al. (2020).

Blending different proportions of WBSO with POo significantly altered the fatty acid profiles of the oil blends. Among the major fatty acids in the oil blends, the content of palmitic acid was reduced by nearly half. The content of oleic acid decreased significantly, while the content of linoleic acid more than doubled and behenic acid tripled in the oil blends compared to POo. Blending $75 \%$ WBSO into POo produced the highest IV of $70.5 \mathrm{~g} \mathrm{I}_{2} / 100 \mathrm{~g}$ oil due to the significant increase in USFA content from $56 \%$ in POo to $64 \%$ in the oil blend. Blending more unsaturated oils into POo have been shown to increase IV and lowered the cloud point as shown in prior studies using soybean, rapeseed and sunflower oils (NorAini et al., 1992; NorAini et al., 1995; Mamat et al., 2005).

Despite the high unsaturation content, the cloud point was highest at $9.7^{\circ} \mathrm{C}$ in the blend with $75 \%$ WBSO while the lowest cloud point of $8.8^{\circ} \mathrm{C}$ was observed in the oil blend containing $50 \%$ WBSO. This may be due to the relatively higher levels of 
Table 2. TAG compositions of palm olein and winged bean (Psophocarpus tetragonolobus) seed oil.

\begin{tabular}{|c|c|c|c|}
\hline \multirow{2}{*}{$\frac{\text { POo }}{\text { TAG }^{1}}$} & \multirow[b]{2}{*}{$\%$} & WBSO & \multirow[b]{2}{*}{$\%$} \\
\hline & & TAG & \\
\hline OLL & $0.5 \pm 0.0$ & LLL + OLLn & $1.6 \pm 0.0$ \\
\hline PLL & $2.8 \pm 0.0$ & OLL & $4.8 \pm 0.1$ \\
\hline MLP & $0.7 \pm 0.0$ & PLL & $2.2 \pm 0.0$ \\
\hline OOL & $2.0 \pm 0.0$ & $\mathrm{OOL}+\mathrm{LLE}$ & $8.4 \pm 0.1$ \\
\hline POL & $10.1 \pm 0.0$ & POL & $4.2 \pm 0.0$ \\
\hline PLP & $10.4 \pm 0.0$ & OLE & $3.4 \pm 0.0$ \\
\hline MPP & $0.3 \pm 0.0$ & OOO & $6.6 \pm 0.0$ \\
\hline OOO & $4.5 \pm 0.0$ & PSL & $2.6 \pm 0.1$ \\
\hline POO & $26.2 \pm 0.0$ & POO & $2.9 \pm 0.0$ \\
\hline POP & $27.6 \pm 0.0$ & SOL & $0.8 \pm 0.0$ \\
\hline PPP & $0.7 \pm 0.0$ & POP & $0.7 \pm 0.1$ \\
\hline SOO & $2.6 \pm 0.0$ & PPP & $1.0 \pm 0.0$ \\
\hline POS & $5.0 \pm 0.0$ & $\mathrm{LLB}+\mathrm{OOE}$ & $11.2 \pm 0.0$ \\
\hline SOS & $0.6 \pm 0.0$ & $\mathrm{SOO}+\mathrm{LLB}$ & $3.2 \pm 0.0$ \\
\hline \multirow[t]{9}{*}{ DAG } & $6.4 \pm 0.0$ & POS & $0.9 \pm 0.0$ \\
\hline & & OLB & $16.2 \pm 0.1$ \\
\hline & & PLB & $4.9 \pm 0.0$ \\
\hline & & OLLg & $4.0 \pm 0.0$ \\
\hline & & OOB & $8.9 \pm 0.0$ \\
\hline & & POB & $2.5 \pm 0.1$ \\
\hline & & $\mathrm{SSLg}+\mathrm{PBB}$ & $3.1 \pm 0.1$ \\
\hline & & Unknown & $4.7 \pm 0.0$ \\
\hline & & DAG & $1.4 \pm 0.3$ \\
\hline
\end{tabular}

\footnotetext{
${ }^{1}$ TAG species: $\mathrm{B}=$ behenoyl; $\mathrm{E}=$ eicosenoyl; $\mathrm{L}=$ linoleoyl; $\mathrm{Lg}=$ lignoceroyl; $\mathrm{Ln}=$ linolenoyl; $\mathrm{O}=$ oleoyl; $\mathrm{P}=$ palmitoyl; $\mathrm{S}=$ stearoyl. WBSO: winged bean (Psophocarpus tetragonolobus) seed oil; POo: palm olein.
}

very long chain saturated fatty acids, i.e., arachidic acid (C20:0), behenic acid (C22:0) and lignoceric acid (C24:0) present in WBSO which affected the overall resistance to clouding of the blends at higher WBSO concentrations. It has been reported that the long chain saturated fatty acids in WBSO could overwhelm the unsaturated fatty acids, particularly if they were esterified at the $s n-1$ and $s n-3$ positions of the TAG backbone (Makeri et al., 2018).

\subsection{Triacylglycerols composition}

The triacylglycerol (TAG) compositions of WBSO and POo are shown in Table 2. Both WBSO and POo consisted of different species of TAG, depending on the fatty acids present in the two oils. For the purpose of discussion, the following nomenclature for TAG will be applied: L, linoleoyl; Ln, linolenoyl; O, oleoyl; P, palmitoyl; E, eicosenoyl; S, stearoyl; $\mathrm{B}$, behenoyl; Lg, lignoceroyl. In WBSO, 26 different TAG species were identified with some co-eluted as critical pairs. The main TAG in WBSO including critical pairs were identified as OLB (16.2\%), LLB + OOE (11.2\%), OOL + LLE $(8.4 \%)$, OOB (8.9\%), OOO (6.6\%), PLB (4.9\%) and OLL $(4.8 \%)$. WBSO also contains approximately $4 \%$ trisaturated

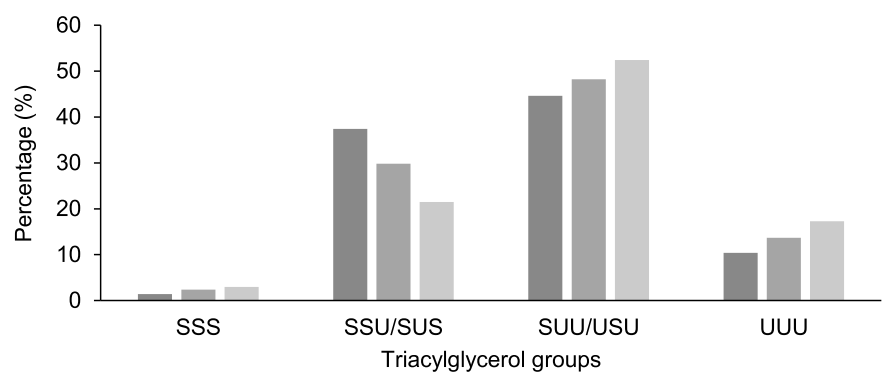

-25\% WBSO: $75 \%$ POo $\square 50 \%$ WBSO : $50 \%$ POo $-75 \%$ WBSO : $25 \%$ POo

Fig. 1. Effect of blending different ratios of palm olein and winged bean (Psophocarpus tetragonolobus) seed oil on triacylglycerol groups. WBSO: winged bean (Psophocarpus tetragonolobus) seed oil; POo: palm olein.

TAG species comprising 1\% PPP and 3\% SSLg + PBB, which consisted mainly of very long chain saturated fatty acids with carbon chain lengths between 18 and 24 such as stearic, behenic and lignoceric acids. This plausibly contributed to the highest cloud point of $9.7^{\circ} \mathrm{C}$ observed with $75 \%$ WBSO addition as discussed earlier. The TAG composition of WBSO reported in this study were in agreement with those reported in earlier studies (Omachi et al., 1987; Makeri et al., 2016, 2018).

There are 14 different TAG species in POo with major TAG comprising POP $(27.6 \%)$ and POO $(26.2 \%)$, followed by PLP (10.4\%), POL (10.1\%) and POS (5.0\%). There was only $1 \%$ total saturated TAG in POo consisting of minute amounts of MPP and PPP. POo contains a lower amount of total triunsaturated TAG which includes OOO, OOL and OLL and totalling to about $7 \%$, compared to the higher level of $21.4 \%$ in WBSO, which is the sum from LLL + OLLn, OLL, OOL + LLE and OOO. About 6.4\% DAG is also present in POo compared to $1.4 \%$ in WBSO. The TAG profile of POo in this study was comparable to that obtained by Hishamuddin et al. (2020).

The TAG species identified in both WBSO and POo can be categorised into different TAG groups (including positional isomers) depending on the level of saturations in the oil. TAG containing all saturated TAG species is designated as trisaturated (SSS), 2 saturated TAG species is disaturated (SSU/SUS), 2 unsaturated TAG species is diunsaturated (SUU/ USU) and all unsaturated TAG is triunsaturated (UUU). Figure 1 depicts the changes in the total concentrations of the TAG groups when WBSO was blended with POo in different proportions. Blending WBSO into POo caused major effects on the sum of the different TAG groups. The SSS, SUU/USU and UUU TAG groups within the blends increased with increasing amount of WBSO added into POo. However, the total amount of SSU/SUS TAG group decreased with the increase in WBSO. The increases in SSS, SUU/USU, UUU and concomitant decrease of SSU/SUS in the blends with increasing WBSO are results of higher levels of these TAG groups present in WBSO. The higher UUU and SUU/USU levels in WBSO had also caused the overall unsaturation levels and IV in the blends to increase. However, higher SSS content in WBSO could also be responsible for the increase in cloud point in the oil blends. The presence of TAG species containing very long-chained saturated fatty acids (C18 to $\mathrm{C} 24)$ such as PSL, PPP, PLB, POB and SSLg + PBB in WBSO is thought to 
Table 3. Thermal behaviour analysis of palm olein and winged bean (Psophocarpus tetragonolobus) seed oil by DSC.

\begin{tabular}{lrllll}
\hline Temperature $\left({ }^{\circ} \mathrm{C}\right)$ & POo & WBSO & $75 \%$ POo: $25 \%$ WBSO & 50\% POo: $50 \%$ WBSO & 25\% POo: $75 \%$ WBSO \\
\hline Offset T (melting) & 27.0 & 23.1 & 25.9 & 23.5 & 21.8 \\
Onset T (crystallisation) & 6.6 & 11.8 & 5.6 & 6.9 & 9.5 \\
\hline
\end{tabular}

WBSO: winged bean (Psophocarpus tetragonolobus) seed oil; POo: palm olein.

confer a significant effect on the saturation levels and cloud points in the blends (Makeri et al., 2018).

\subsection{Thermal behaviour by DSC}

Thermal behaviour analysis by DSC was evaluated for all blends generated from WBSO and POo. The onset crystallisation temperatures and offset melting temperatures of all samples are tabulated in Table 3 while Figure 2 illustrates the DSC thermograms of the melting and crystallisation behaviour of WBSO, POo and their blends. Higher onset temperatures for crystallisation in the blends with increasing proportions of WBSO corresponded with the decrease in offset melting temperatures. This was observed in the shift of the offset melting temperature from higher melting region towards lower temperatures with the increase in the proportion of WBSO in the blends. This finding further supports the increase in unsaturation levels observed when higher amounts of WBSO were blended into POo. Similar DSC results were obtained by Myat et al. (2009) in their study on blends of POo and peanut oil, in which peanut oil is more unsaturated in nature compared to POo.

The onset crystallisation temperatures shifted towards higher temperature regions with increasing WBSO proportions in the oil blends. This may be due to a higher amount of SSS TAG present in WBSO (Tab. 2), as depicted by the characteristic sharp peak at higher temperatures in WBSO and blends containing WBSO, which began to crystallise at higher temperatures compared to POo. Similar findings were reported by Makeri et al. (2016) who ascribed this peak to minor and high melting TAG constituents. The melting and crystallisation thermograms of POo obtained in this study were similar to that observed by Tan and Che Man (2002). The effect of blending WBSO with POo generated broad curves and multiple peaks within the melting and crystallisation thermograms, signifying the complexity of the thermal behaviour of the different TAG species and groups within the blends.

\section{Conclusions}

In this study, blends of WBSO and POo at predetermined ratios were evaluated for its physicochemical properties. WBSO contains a higher percentage of unsaturated FA and TAG compared to POo, making it a suitable oil for blending to improve the physicochemical properties of POo. The addition of higher WBSO proportions into POo resulted in the increase in IV, unsaturation levels and lower cloud point of the oil blends. Blending WBSO with POo modified the physicochemical characteristics of the oils, and resulted in a novel oil blend with enhanced unsaturation levels and improved
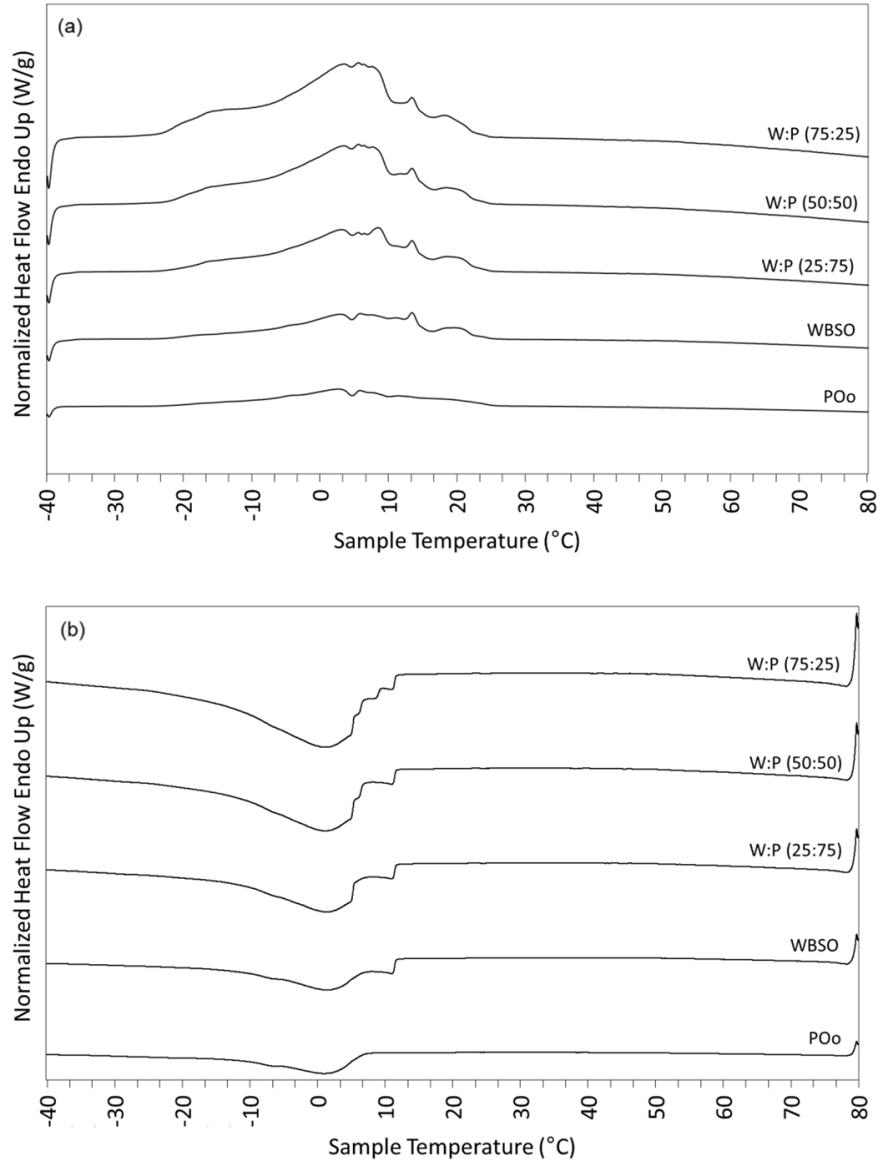

Fig. 2. DSC thermograms of (a) melting and (b) crystallisation of blends of WBSO and POo. WBSO/W: winged bean (Psophocarpus tetragonolobus) seed oil; POo/P: palm olein.

cloudiness resistance. The results from this study have demonstrated that unconventional oils such as WBSO could potentially enhance the functional aspects of palm-based products for higher value addition and manufacturing of oil products with the desired quality and characteristics.

Acknowledgements. The authors wish to thank the Director General of the Malaysian Palm Oil Board (MPOB) for permission to publish this paper. Technical assistance from the Innovative Products Group is highly acknowledged.

Conflict of interest. The authors declare that they have no conflicts of interest in relation to this article. 


\section{References}

Adhikari P, Zhu XM, Gautam A, et al. 2010. Scaled-up production of zero-trans margarine fat using pine nut oil and palm stearin. Food Chem 119: 1332-1338.

American Oil Chemists' Society (AOCS). 2013. Official methods and recommended practices of the AOCS, 6th ed. Champaign: AOCS Press.

Černý K, Kordylas M, Pospíšil F, Švábenský O, Zajic B. 1971. Nutritive value of the winged bean (Psophocarpus palustris Desv.). Br J Nutr 26: 293-299.

Dollah S, Abdulkarim SM, Ahmad SH, Khoramnia A, Ghazali HM. 2014. Physicochemical properties and potential food applications of Moringa oleifera seed oil blended with other vegetable oils. $J$ Oleo Sci 63: 811-822.

Ekpenyong TE, Borchers RL. 1980. The fatty acid composition of the oil of the winged bean (Psophocarpus tetragonolobus L.) seeds. $J$ Amer Oil Chem Soc 57: 147-149.

Garcia VV, Palmer JK, Young RW. 1979. Fatty acid composition of the oil of winged beans (Psophocarpus tetragonolobus (L.) DC). J Amer Oil Chem Soc 56: 931-932.

Hashempour-Baltork F, Torbati M, Azadmard-Damirchi S, Savage GP. 2016. Vegetable oil blending: A review of physicochemical, nutritional and health effects. Trends Food Sci Technol 57: 52-58.

Higuchi M, Terao J, Iwai K. 1982. Gas chromatography-mass spectrometric determination of fatty acids in seed oil of winged bean (Psophocarpus tetragonolobus (L.) DC). J Nutr Sci Vitaminol 28: 511-518.

Hishamuddin E, Nagy ZK, Stapley AG. 2020. Thermodynamic analysis of the isothermal fractionation of palm oil using a novel method for entrainment correction. J Food Eng 273: 109806.

Homma S, Omachi M, Tamura A, Ishak E, Fujimaki M. 1983. Lipid composition of winged bean (Psophocarpus tetragonolobus). J Nutr Sci Vitaminol 29: 375-380.

Jahurul MHA, Zaidul ISM, Norulaini NN, et al. 2014. Hard cocoa butter replacers from mango seed fat and palm stearin. Food Chem 154: 323-329.

Kadam SS, Salunkhe DK, Luh BS. 1984. Winged bean in human nutrition. Crit Rev Food Sci Nutr 21: 1-40.

Lepcha P, Egan AN, Doyle JJ, Sathyanarayana N. 2017. A review on current status and future prospects of winged bean (Psophocarpus tetragonolobus) in tropical agriculture. Plant Foods Hum Nutr 72: 225-235.

Makeri MU, Karim R, Abdulkarim MS, Ghazali HM, Miskandar MS, Muhammad K. 2016. Comparative analysis of the physicochemical, thermal and oxidative properties of winged bean and soybean oils. Int J Food Prop 19: 2769-2787.

Makeri MU, Ghazali H, Salihu A Igwegbe AO, Muhammad K. 2018. Stereospecific positional distribution of fatty acids and frying properties of winged bean (Psophocarpus tetragonolobus DC) and soybean (Glycine max.) oils. Niger Food J 35: 71-82.

Makeri M, Sahri MM, Ghazali HM, Ahmad K, Muhammad K. 2019. Polymorphism, textural and crystallization properties of winged bean (Psophocarpus tetragonolobus, DC) oil-based trans-fatty acids free ternary margarine blends. LWT 100: 158-166.
Malaysia Palm Oil Board (MPOB). 2020. Available from http://bepi. mpob.gov.my/index.php/en/production/production-2020/produc tion-of-processed-palm-oil-2020.html (last consult.: 2021/20/04).

Mamat H, Aini IN, Said M, Jamaludin R. 2005. Physicochemical characteristics of palm oil and sunflower oil blends fractionated at different temperatures. Food Chem 91: 731-736.

Mohanty CS, Verma S, Singh V, et al. 2013. Characterization of winged bean (Psophocarpus tetragonolobus (L.) DC.) based on molecular, chemical and physiological parameters. Am J Mol Biol 3: 187-197.

Mohanty CS, Pradhan RC, Singh V, et al. 2014. Physicochemical analysis of Psophocarpus tetragonolobus (L.) DC seeds with fatty acids and total lipids compositions. J Food Sci Technol 52: 3660 3670.

Mohanty CS, Syed N, Kumar D, et al. 2021. Chemical characterization of winged bean (Psophocarpus tetragonolobus (L.) DC. seeds and safety evaluation of its fatty oil. J Food Meas Charact 15: $807-16$.

Myat MW, Abdulkarim SM, Ghazali HM, Roselina K. 2009. Physicochemical and sensory characteristics of palm olein and peanut oil blends. J Food Agric Environ 7: 175-181.

NorAini I, Hanirah H, Oh FCH, Sudin N. 1992. Resistance to crystallization of blends of palm olein with soybean oil stored at various temperatures. J Amer Oil Chem Soc 69: 1206-1209.

NorAini I, Hanirah H, Sudin N, Oh FC, Tang TS. 1995. Clarity of blends of double-fractionated palm olein with low-erucic acid rapeseed oil. J Amer Oil Chem Soc 72: 443-448.

NorAini I, Hanirah H. 1996. Clarity of blends of double-fractionated palm olein with low-erucic acid rapeseed oil. Elaeis 8: 104-113.

Omachi M, Homma S, Fujimaki M. 1987. Triacylglycerol composition of winged bean (Psophocarpus tetragonolobus). J Nutr Sci Vitaminol 33: 49-54.

Parveez GKA, Hishamuddin E, Loh SK, et al. 2020. Oil palm economic performance in Malaysia and R\&D progress in 2019. $J$ Oil Palm Res 32: 159-190.

Salama MA, El Harkaoui S, Nounah I, et al. 2020. Oxidative stability of Opuntia ficus-indica seeds oil blending with Moringa oleifera seeds oil. OCL 27: 53.

Saw MH, Hishamuddin E, Fauzi SHM, Yeoh CB, Lim WH. 2020. Influence of polyglycerol ester additive on palm oil fractionation in relation to the crystal size distribution. J Oil Palm Res 32: 303-312.

Siddique BM, Ahmad A, Ibrahim MH, Hena S, Rafatullah M. 2010. Physico-chemical properties of blends of palm olein with other vegetable oils. Grasas aceites 61(4): 423-429.

Siew WL, Ng WL. 1996. Characterisation of crystals in palm olein. $J$ Sci Food Agric 70: 212-216.

Sonwai S, Ornla-Ied P, Aneknun T. 2015. Lauric fat cocoa butter replacer from krabok (Irvingia malayana) seed fat and coconut oil. J Oleo Sci 64: 357-365.

Tan CP, Man YC. 2002. Differential scanning calorimetric analysis of palm oil, palm oil based products and coconut oil: effects of scanning rate variation. Food Chem 76: 89-102.

Zaliha O, Chong CL, Cheow CS, Norizzah AR, Kellens MJ. 2004. Crystallization properties of palm oil by dry fractionation. Food Chem 86: 245-25.

Cite this article as: Hishamuddin E, Saw MH. 2022. Enhancement of physicochemical characteristics of palm olein and winged bean (Psophocarpus tetragonolobus) seed oil blends. OCL 29: 2. 